\title{
PERUBAHAN FISIKO-KIMIA CABAI PUYANG (PIPER RETROFRACTUM VAHL.) PADA PENGERINGAN HOT AIR DRYER
}

\author{
Physicochemical Changes of Puyang Chili (Piper retrofractum Vahl.) Dried on Hot Air \\ Dryer
}

La Choviya Hawa*, Nur Ida Winni Yosika, Amirada Nur Laily, Firdiani Nur Affifah, Dewi Maya Maharani

Jurusan Keteknikan Pertanian - Fakultas Teknologi Pertanian - Universitas Brawijaya

Jl. Veteran - Malang 65145

Penulis Korespondensi, email : la_choviya@ub.ac.id

Disubmit: 12 Maret 2020 Direvisi: 11 Juni 2020 Diterima: 17 Juli 2020

\begin{abstract}
ABSTRAK
Cabai puyang (Piper retrofractum Vahl.) adalah komoditas tanaman herbal yang merupakan tanaman asli Asia Tenggara, terutama Indonesia. Komoditas ini umumnya dimanfaatkan sebagai bahan baku jamu dan bumbu dapur. Di kalangan akademisi, cabai puyang banyak mendapatkan perhatian karena sifat anti kanker, anti mikroba, dan potensial sebagai anti virus demam berdarah. Salah satu proses terpenting dalam pengolahan cabai puyang adalah pada proses pengeringan. Blanching dipilih sebagai pra-perlakuan sebelum pengeringan untuk mempercepat proses pengeringan dan mempertahankan kualitas produk cabai puyang kering. Tujuan dari penelitian ini adalah untuk mengetahui pengaruh blanching pada mikrostruktur, kadar air, sifat fisik, dan kandungan kimiawi cabai puyang kering menggunakan hot air dryer pada suhu 50,60 dan $70^{\circ} \mathrm{C}$. Hasil penelitian menunjukkan bahwa perlakuan blanching menyebabkan kerusakan pada dinding sel cabai puyang, tekstur melunak sehingga penurunan kadar air pada sampel blanching lebih cepat dibanding nontreatment. Perubahan sifat fisik berupa dimensi terjadi secara cepat pada sepertiga waktu pengeringan awal. Perubahan massa sampel nontreatment dan blanching pada akhir pengeringan relatif sama pada kisaran $31,8 \%$. Kandungan antioksidan, fenol dan piperin pada sampel nontreatment relatif lebih tinggi daripada sampel blanching pada seluruh suhu pengeringan.
\end{abstract}

Kata Kunci : Antioksidan; Cabai Puyang; Fenol; Kadar Air; Piperin; Sifat Fisik

\begin{abstract}
Puyang chili (Piper retrofractum Vahl) is a native herb comodity in Southeast Asia, especially in Indonesia. This comodity used as tradisional drink (jamu) and spices. Chili has anti-cancer and antrimicrobial effects, as well as potential for anti-dengue virus. Drying process is comonnly used for food perservative including chili. Blanching as a pretreatment can increase drying rate and maintain quality of dried products. The aim of this research were to evaluate the effect of blanching on microstructrure, moisture content, physical and chemical properties of dried puyang chili which used hot air dryer at different temperature: 50, 60 and $70^{\circ} \mathrm{C}$. The results showed that blanching treatment caused damage to the cell walls of chilies, softened texture so that the decrease of water content in blanching samples were faster than nontreatment. Changes in physical properties in the form of dimensions occured quickly in one third of the initial drying time. The change of mass in treated and non-treated samples were relatively the same which ranged of $31.8 \%$. The antioxidant, phenol and piperine content in non-treatment samples are relatively higher than blanching samples at all drying temperatures tested.
\end{abstract}

Keywords : Antioxidant; Puyang Chili; Moisture Content; Phenolic Content; Piperine; Physical Properties 


\section{PENDAHULUAN}

Cabai puyang merupakan tanaman herbal yang banyak dimanfaatkan sebagai minuman tradisional (jamu) dan bumbu, yang memiliki rasa dan aroma tajam yang unik, dan juga digunakan untuk berbagai keperluan terapi, karena cabai puyang mengandung komponen obat, termasuk piperin alkaloid yang berasa pedas dan senyawa fenolik lainnya (Luyen et al., 2014). Senyawa fenolik ini memiliki efek anti-obesitas (Kim et al., 2011), hepatoprotektif (Matsuda et al., 2009), dan memiliki efek antioksidan (Chonpathompikunlert et al., 2010).

Salah satu sentra produksi cabai puyang berada di Pulau Madura, khususnya di Kabupaten Sumenep. Berdasarkan data pemerintah daerah setempat pada 2009, luas tanaman cabai puyang di kabupaten tersebut adalah 1685 ha dengan total produksi 8335 ton, atau memiliki produktivitas 4,95 ton/ha. Cabai puyang mempunyai kadar air yang tinggi sekitar $70-75 \%$ sehingga mudah busuk apabila tidak men-dapat penanganan dengan benar (Orsat et al., 2006).

Pengeringan cabai puyang dapat menghentikan proses pembusukan dan reaksi enzimatis lainnya. Umumnya, petani melakukan pengeringan cabai puyang secara langsung di bawah sinar matahari selama 3-5 hari untuk memperoleh kadar air yang sesuai standar pasar. Namun kelemahannya penyusutan cabai puyang cukup besar sehingga terjadi penyusutan rendemen.

Blanching merupakan salah satu metode pra-perlakuan untuk pengeringan yang bertujuan untuk mempertahankan warna dan meng-inaktivasi enzim. Metode blanching pada buah dan sayuran yang melibatkan panas dengan waktu yang singkat (Pandey et al., 2019). Blanching juga dapat menurunkan kadar air bahan sehingga pengeringan akan mempercepat pengringan (Pardede et al., 2017). Hal ini disebabkan karena saat proses blanching, terjadi pengeluaran udara yang terperangkap dalam jaringan tanaman dengan melunakkan tekstur buah akibat perubahan polimer dinding sel (Xiao et al., 2017).

Meski proses pengeringan dalam pascapanen cabai puyang cukup penting, belum ada riset sebelumnya mengenai efek blanching pada mikrostruktur cabai puyang, pengeringan cabai puyang, perubahan sifat fisik dan kandungan kimiawi cabai puyang kering.
Tujuan dari penelitian ini adalah untuk mengetahui pengaruh blanching pada mikrostruktur cabai puyang, perubahan kadar air, sifat fisik, dan kandungan kimia-wi cabai puyang kering dengan metode pengeringan hot air dryer pada suhu 50,60 , dan $70^{\circ} \mathrm{C}$.

\section{METODE}

Peralatan yang digunakan dalam penelitian ini adalah tray dryer, scanning electron microscopy (FEI Inspect S50), oven tipe Memmert/UFE 550, hygrometer, timbangan digital (PL303 series, Mettler Toledo, USA), waterbath, stopwatch, dan digital caliper dengan ketelitian $\pm 0,01 \mathrm{~mm}$

Buah cabai puyang didapatkan dari petani di Desa Nguling, Pasuruan, Jawa Timur digunakan untuk semua percobaan dalam penelitian ini. Buah cabai puyang yang sudah matang berwarna oranye kemerahan dipilih berukuran antara 2,5- $3 \mathrm{~cm}$. Pada penelitian ini, kadar air diuji sebanyak lima kali ulangan, pengujian sifat fisik sejumlah 25 sampel cabai puyang dengan tiga kali ulangan dan kandungan antioksidan, fenol, dan piperin masing-masing sebanyak tiga kali ulangan. Penentuan kadar air awal cabai puyang dilakukan dengan metode gravimetri atau pengeringan oven pada suhu $105 \pm 1{ }^{\circ} \mathrm{C}$ selama 4 jam.

Pengeringan dilakukan dengan 2 variasi pra-perlakuan sebelum pengeringan yaitu nontreatment (tanpa pra-perlakuan) dan blanching. Metode blanching yang digu-nakan yaitu water blanching dengan air mendidih $70 \pm 2{ }^{\circ} \mathrm{C}$ selama 3 dan 5 menit. Pengeringan dilakukan menggunakan tray dryer pada suhu 50,60, dan $70{ }^{\circ} \mathrm{C}$ selama 24 jam sehingga diharapkan kadar air keseimbangan telah tercapai. Selama pengeringan, perubahan massa cabai puyang ditimbang setiap 15 menit pada 2 jam pertama dan setiap 30 menit sampai akhir pengeringan. Penentuan massa padatan dilakukan de-ngan metode gravimetri pada suhu $105{ }^{\circ} \mathrm{C}$ selama 4 jam.

Kadar air dihitung menggunakan Persamaan 1.

kadar air(thobj $\quad \frac{m_{i v} m_{v}}{m_{i v}} \times 100 \%$

dimana $\mathrm{m}_{\mathrm{ap}}$ adalah massa air dan padatan; serta $\mathrm{m}_{\mathrm{p}}$ adalah massa padatan. 


\section{Pengukuran Atribut Sifat Fisik}

Pengukuran atribut fisik dimensi linear meliputi panjang, lebar, dan tebal yang diukur menggunakan pengukur caliper digital dengan keakuratan 0,01 mm. Massa setiap cabai puyang ditimbang menggunakan timbangan digital dengan tingkat keakuratan 0,001 g. Semua atribut fisik dihitung sebagai nilai relatif (\% kontrol), yang dihitung menggunakan Persamaan 2.

$\%$ kontrol $=\left(\mathrm{N}_{\text {sampel }} / \mathrm{N}_{\text {kontrol }}\right) \times 100$

dengan $\mathrm{N}_{\text {kontrol }}$ adalah nilai sifat fisik sebe-lum pengeringan (kontrol) dan $\mathrm{N}_{\text {sampel }}$ ada-lah sifat fisik setelah pengeringan (sampel).

\section{HASIL DAN PEMBAHASAN}

\section{Efek Waktu Blanching Pada Struktur Sel}

Pengamatan struktur sel cabai puyang segar dan cabai puyang yang di-blanching selama 3 dan 5 menit. Pengamatan meng- gunakan scanning electron microscopy pada perbesaran 250x.

Pada Gambar 1(a) tampak bahwa pada cabai puyang segar struktur dinding selnya masih tegar, terlihat jelas dan dipenuhi banyak pati. Blanching 3 menit (Gambar 1(b)) menyebabkan dinding sel banyak yang terbuka, pecah dan berlubang. Blanching selama 5 menit (Gambar 1(c)) menyebabkan kerusakan yang meluas di seluruh permukaan dinding sel, dinding sel mengerut dan butiran pati tidak nampak lagi. Proses blanching menyebabkan kerusakan pada dinding sel, melunakkan tekstur dan menginaktivasi enzim penyebab pencoklatan (Pandey et al., 2019). Proses blanching pada cabai puyang dilakukan untuk mempercepat proses pengeringan karena dinding selnya lunak (Xiao et al., 2017), sehingga transfer air akan lebih mudah. Penggunaan suhu tinggi pada pengeringan akan menyebabkan pengerutan pada dinding sel karena kadar airnya menjadi semakin rendah (Wibisono et al., 2019)

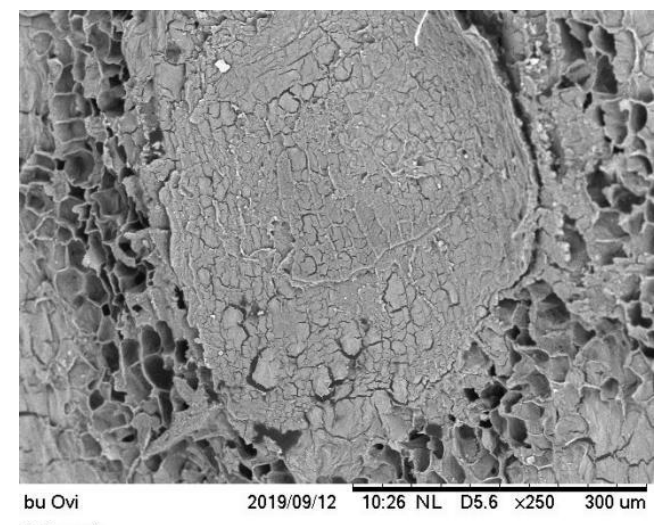

B.3 menit

(b)

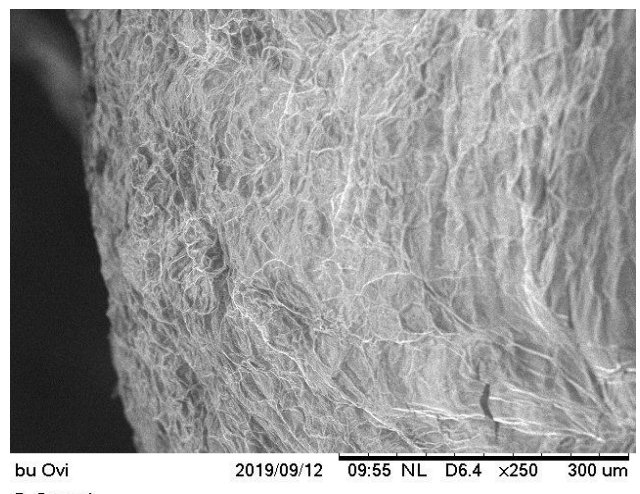

(c)

Gambar 1. Struktur sel cabai puyang (a) segar, (b) blanching 3 menit dan (c) blanching 5 menit 


\section{Kadar Air}

Perubahan kadar air cabai puyang pada sampel non-treatment dan blanching pada hot air drying pada suhu 50,60, dan $70^{\circ} \mathrm{C}$ ditunjukkan pada Gambar 2. Pada Gambar 2 tampak bahwa cabai puyang yang diberi perlakuan blanching lebih cepat turun kadar airnya pada awal sampai pertengahan pengeringan. Waktu yang dibutuhkan untuk mengeringkan cabai puyang blanching juga lebih cepat. Blanching mampu mengurangi kekerasan struktur sel, pengerutan produk kering dan mengurangi efek browning pada produk akhir. Blanching memodifikasi struktur jaringan menyebabkan perpindahan massa air dari bahan ke ruang pengering semakin mudah dan cepat (Pimpaporn et al., 2007). Blanching juga membantu memfasilitasi perpindahan air dimana sebagian struktur sel melemah, yang me-mungkinkan migrasi air pada saat penge-ringan lebih mudah (Hawa et al., 2014). Ca-bai puyang termasuk bahan yang sensitif terhadap panas, sehingga waktu blanching ditetapkan selama 3 menit berdasarkan hasil SEM.

Kenaikan suhu dalam ruang pengering juga memberi pengaruh positif terhadap penu-runan kadar air. Pada suhu 70C, penurunan kadar air cabai puyang lebih cepat dibanding pada suhu 50 dan $60^{\circ} \mathrm{C}$. Di sisi lain, waktu yang diperlukan untuk mencapai kadar air keseimbangan lebih cepat tercapai pada suhu pengeringan $70^{\circ} \mathrm{C}$. Peningkatan suhu akan mempercepat proses perpindahan massa air dari bahan ke ruang pengering (Takahashi et al., 2017). Hal ini juga sesuai dengan hasil penelitian Hawa et al., (2019) pada pengeringan chips talas

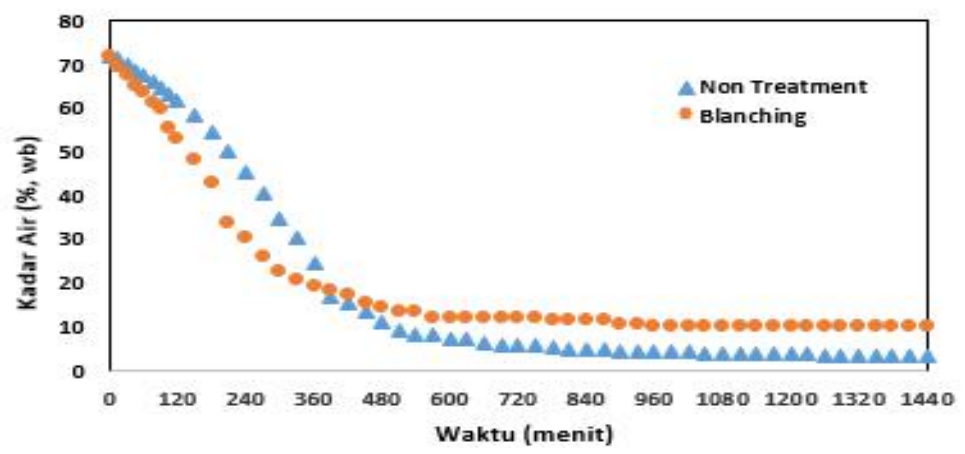

(a)

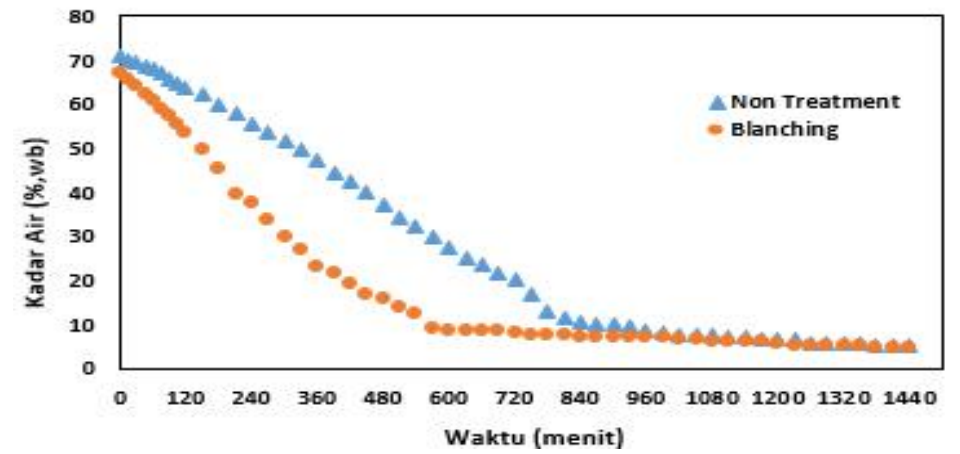

(b)

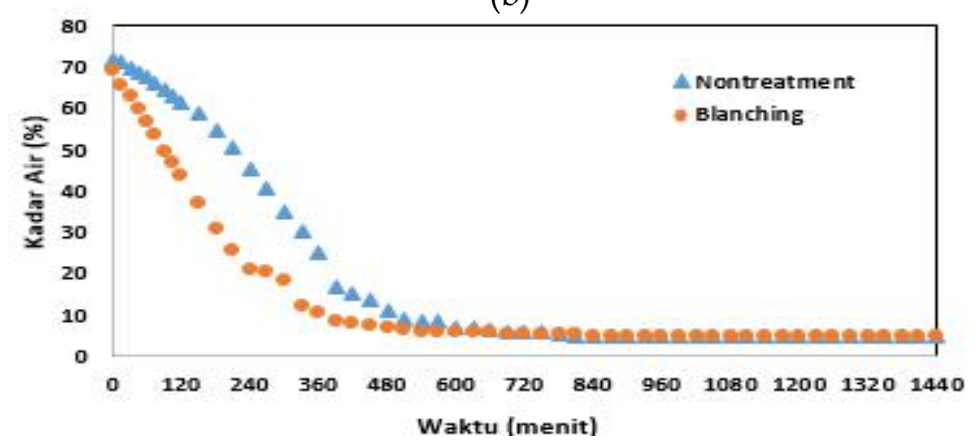

(c)

Gambar 2. Perubahan kadar air selama Pengeringan pada suhu (a) $50^{\circ} \mathrm{C}$, (b) $60{ }^{\circ} \mathrm{C}$, dan (c) $70{ }^{\circ} \mathrm{C}$ 


\section{Sifat Fisik}

Perubahan karakteristik fisik (massa, panjang, lebar dan tebal) selama pengeringan ditunjukkan pada Tabel 1. Pada penelitian ini cabai puyang dipanen pada waktu dan umur panen yang sama karena perilaku pengeringan sangat dipengaruhi oleh faktor internal seperti komposisi materi, kadar air, ketebalan, geometri, dan struktur awal (Karam et al., 2016). Kondisi awal (massa, panjang, lebar dan tebal) pada bahan segar (sebelum dikeringkan) diasumsikan berada pada nilai maksimum yaitu $100 \%$.

Secara umum, perubahan geometri cabai puyang yang meliputi massa, panjang, lebar dan tebal pada sampel non-treatment dan blanching pada tiga hingga enam jam awal pengeringan terjadi secara cepat dan mulai melambat pada jam ke-12 dan konstan hingga jam ke-24. Perubahan panjang, lebar dan tebal sampel blanching lebih lambat daripada sampel non-treatment. Hal ini menunjukkan bahwa perlakuan blanching mampu menghambat pengerutan pada cabai puyang. Namun demikian, secara umum perubahan massa pada akhir pengeringan pada sampel non-treatment maupun blanching tidak ada perbedaan, yaitu pada kisaran $31,8 \%$. Hal ini menunjukkan bahwa pretreatment blanching tidak menyebabkan kehilangan massa padatan pada saat proses pengeringan.

\section{Kandungan Antioksidan}

Kandungan antioksidan $\mathrm{IC}_{50}$ pada cabai puyang kering ditunjukkan pada Gambar 3. Perlakuan suhu pada pengeringan pada tray dryer berdampak pada penurunan antioksidan. Kandungan antioksidan sampel blanching lebih rendah karena adanya pemberian panas sehingga menurunkan kandungan antioksidannya. Penurunan ini erat kaitannya karena keberadaan antioksidan pada bagian kulit luar cabai puyang sehingga sangat dipengaruhi dengan temperatur pemanasan dalam mesin pengering (Nakatani et al., 1986; Takahashi et al., 2017).

\section{Kandungan Fenol}

Kandungan fenol cabai puyang kering ditunjukkan pada Gambar 4. Kandungan fenol sampel blanching lebih rendah dari sampel non-treatment karena adanya pemberian panas selama proses blanching sehingga menurunkan kandungan fenolnya. Penelitian terdahulu menunjukkan bahwa Piperaceae mengandung konstituen fenolik, dimana amida fenolik adalah senyawa dominan; dan cabai puyang menunjukkan sifat antioksidan yang signifikan (Nakatani et al., 1986).

\section{Kandungan Piperin}

Kandungan piperin pada cabai puyang kering ditunjukkan pada Gambar 5. Kandungan piperin sampel blanching sedikit lebih rendah dari sampel non-treatment. Hal ini sesuai dengan penelitian Takahashi et al., (2017) yang menyatakan bahwa kandungan piperin pada cabai puyang kering relatif konstan mulai awal pengeringan hingga akhir pengeringan baik pada metode pengeringan di bawah matahari terbuka maupun pengeringan dalam oven. Hal ini dikarenakan bahwa piperin lebih banyak terdistribusi di dalam buah bukan di permukaan buah, sehingga terjaga dari pengaruh iradiasi UV dan juga temperatur mesin pengering (Nair, 2004; Nisha et al., 2009).

\section{SIMPULAN}

Kesimpulan dari penelitian ini diambil berdasarkan hasil penelitian menunjukkan bahwa perlakuan blanching menyebabkan kerusakan pada dinding sel, pelunakan tekstur dan mempercepat proses pengeringan karena transfer air dari bahan ke ruang pengering lebih mudah. Perubahan sifat fisik berupa dimensi panjang, lebar dan tebal terjadi secara cepat pada sembilan jam awal pengeringan. Perubahan massa sampel nontreatment dan blanching pada akhir pengeringan relatif sama pada kisaran $31,8 \%$. Kandungan antioksidan, fenol, dan piperin pada sampel non-treatment relatif lebih tinggi daripada sampel blanching pada seluruh suhu pengeringan. Efek pemberian panas selama blanching akan meluruhkan sebagian dari kandungan kimia cabai puyang. 


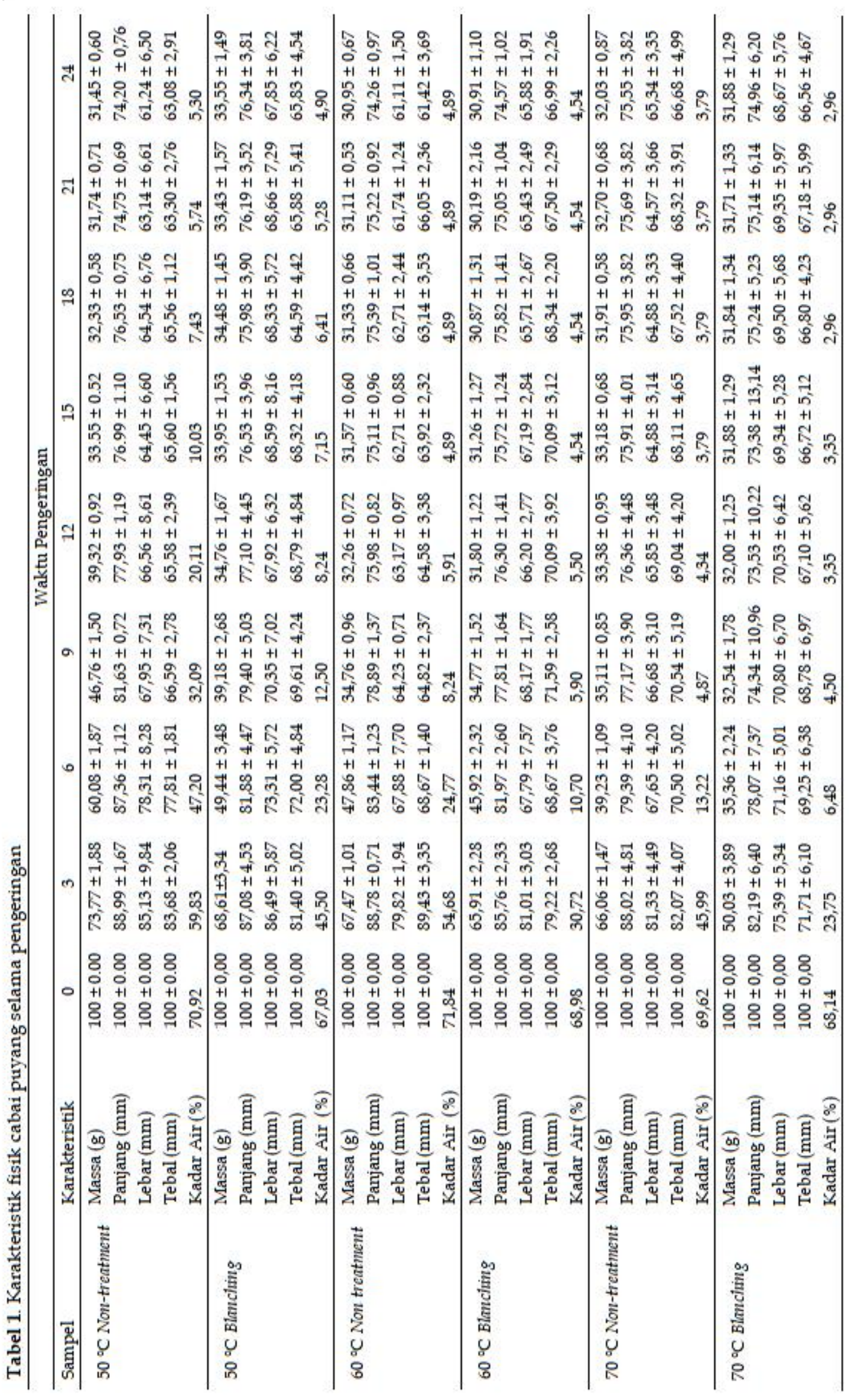




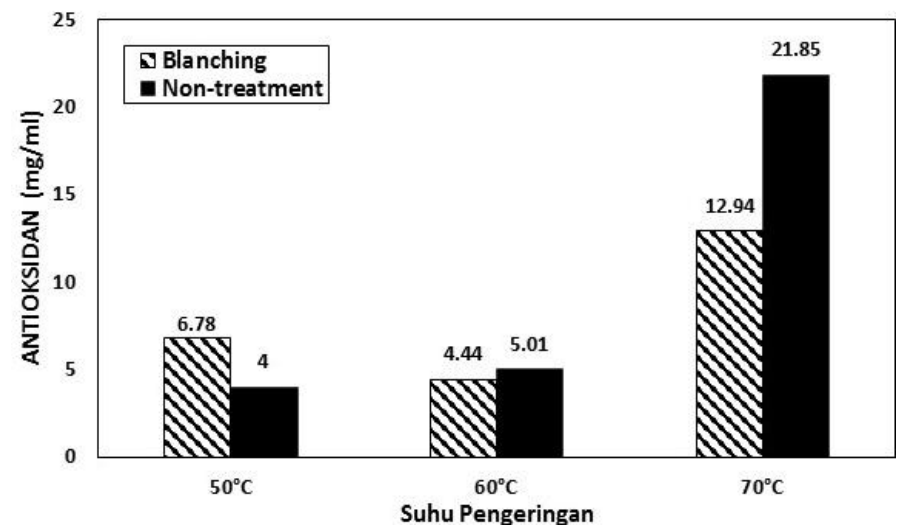

Gambar 3. Kandungan antioksidan cabai puyang kering

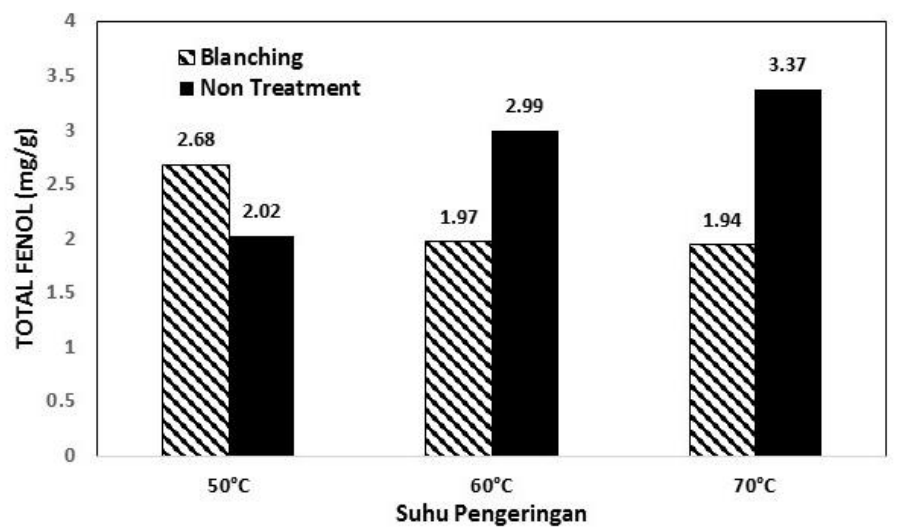

Gambar 4. Kandungan fenol cabai puyang kering

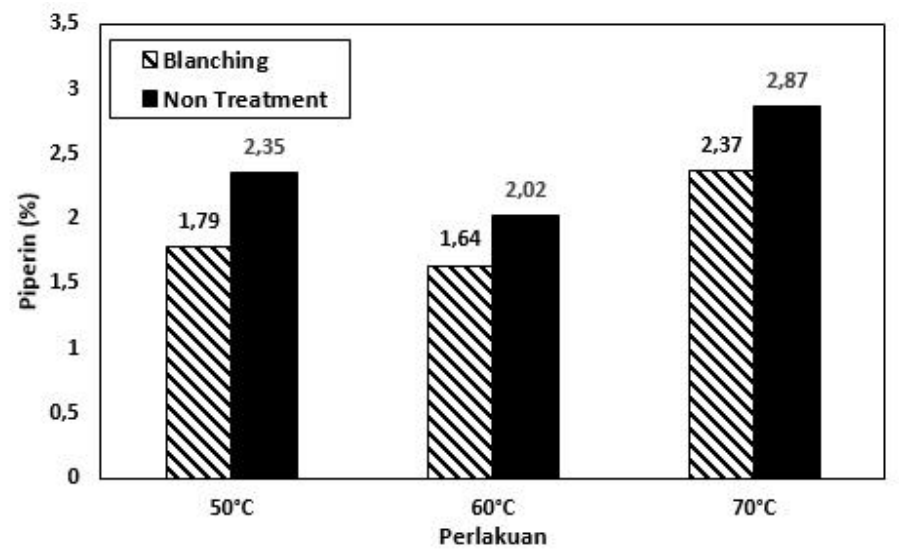

Gambar 5. Kandungan piperin cabai puyang kering

\section{DAFTAR PUSTAKA}

Chonpathompikunlert, P., Wattanathorn, J., Muchimapura, S., 2010. Piperine, the main alkaloid of Thai black pepper, protects against neurodegeneration and cognitive impairment in animal model of cognitive deficit like condition of Alzheimer's disease. Food and Chemical Toxicology. 48, 798-802. https://doi.org /10.1016/j.fct.2009.12.009

Hawa, L, C., Ali, S, B., Fujii, S., Yoshimoto, N., Yamamoto, S., 2014. Effects of pretreatments on browning of lemon peels 
during drying. Japan Journal of Food Engineering. 15(3), 181-187. https:// doi. org/10.11301/jsfe.15.181

Hawa, L, C., Ubaidillah, U., Wibisono, Y., 2019. Proper model of thin layer drying curve for taro (Colocasia esculenta L. Schott) chips. International Food Research Journal. 26(1), 209-216. http:/ / www.ifrj. upm.edu.my $/ 26 \% 20(01) \% 202019 /(23)$.p df

Karam, M, C., Petit, J., Zimmer, D., Djantou, E, B., Scher, J., 2016. Effects of drying and grinding in production of fruit and vegetable powders: A review. Journal of Food Engineering. 188, 32-49. https:// doi.org/10.1016/j.jfoodeng.2016.05.001

Kim, K, J., Lee, M, S., Jo, K., Hwang, J, K., 2011. Piperidine alkaloids from Piper retrofractum Vahl. protect against highfat diet-induced obesity by regulating lipid metabolism and activating AMPactivated protein kinase. Biochemical and Biophysical Research Communications. 411, 219-225. https:// doi.org/10.1016/j.bbrc. 2011.06.153

Luyen, B, T, T., Tai, B, H., Thao, N, P., Yang, S, Y., Cuong, N, M., Kwon., Y, I., Kim, Y, H., 2014. A new phenylpropanoid and an alkylglycoside from Piper retrofractum leaves with their antioxidant and a-glucosidase inhibitory activity. Bioorganic \& Medical Chemistry Letters. 24, 4120-4124. https://doi.org/10.1016 /j.bmcl.2014.07.057

Matsuda, H., Ninomiya, K., Morikawa, T., Yasuda, D., Yamaguchi, I., Yoshikawa, M., 2009. Hepatoprotective amide constituents from the fruit of Piper chaba: Structural requirements, mode of action, and new amides. Bioorganic \& Medical Chemistry. 17, 7313-7323. https://doi .org/10.1016/j.bmc.2009.08.050matsuda

Nair, K, P, P., 2004. The agronomy and economy of black pepper (Piper nigrum L.)-The King of Spices. Advances in Agronomy. 82, 271-389. https://doi.org /10.1016/B978-0-12-391865-9.000013nair

Nakatani, N., Inatani, R., Ohta, H., Nishioka, A., 1986. Chemical constituents of peppers (Piper spp.) and application to food preservation: Naturally occurring antioxidative compounds. Environmental Health Perspectives. 67, 135-142. https:// //doi.org/10.1289/ehp.8667135
Nisha, P., Singhal, R, S., Padit, A, B., 2009. The degradation kinetics of flavor in black pepper (Piper nigrum L.). Journal of Food Engineering. 92, 44-49. https://doi. org/10.1016/j.jfoodeng.2008.10.018

Orsat, V., Changrue, V., Raghavan, G, S, V., 2006. Microwave drying of fruits and vegetables. Stewart Postharvest Review. 6, 4-9. https:// doi.org/10.2212/spr.2006. .6 .4

Pandey, O, P., Mishra, B, M., Misra, A., 2019. Comparative study of green peas using with blanching and without blanching techniques. Information Processing in Agriculture. 6, 285-296. https://doi.org/ 10.1016/j.inpa.2018.10.002

Pardede, M, C., Julianti, E., Ridwansyah. 2017. Pengaruh suhu blansing dan suhu pengeringan terhadap mutu fisik tepung ubi jalar ungu (Ipomea batatas L.). Jurnal Rekayasa Pangan dan Pertanian. 5(3), 469-477. https://jurnal.usu.ac.id/ index.php/jrpp/article/view/Magdale na\%20Cristina\%20Pardede

Pimpaporn, P., Devahastin, S., Chiewchan, N., 2007. Effects of combined pretreatments on drying kinetics and quality of potato chips undergoing lowpressure superheated steam drying. Journal of Food Engineering. 81, 318-329. https://doi.org/10.1016/j.jfoodeng.200 6.11 .009

Takahashi, M., Ohshiro, M., Ohno, S., Yonamine, K., Arakaki, M., Wada, K., 2017. Effects of solar and oven-drying on physicochemical and antioxidant characteristics of hihatsumodoki (Piper retrofractum Vahl) fruit. Journal of Food Processing and Preservation. 42(2), 1-9. https://doi.org/10.1111/jfpp.13469

Wibisono, Y., Ubaidillah, U., Hawa, L, C., 2019. Microstructure changes of taro (Colocasia esculenta L.Schott) chips and grains during drying. IOP Conference Series: Earth and Environmental Science. 230, 1-7. http://doi.org/10.1088/17551315/230/1/012008

Xiao, H, W., Pan, Z., Deng, L, Z., El-Mashad, M., Yang, X., Mujumdar, A, S., Gao, Z., Zhang, Q., 2017. Recent developments and trends in thermal blanching - A comprehensive review. Information Processing in Agriculture. 4, 101-127. https://doi.org/10.1016/j.inpa.2017.02. 001 